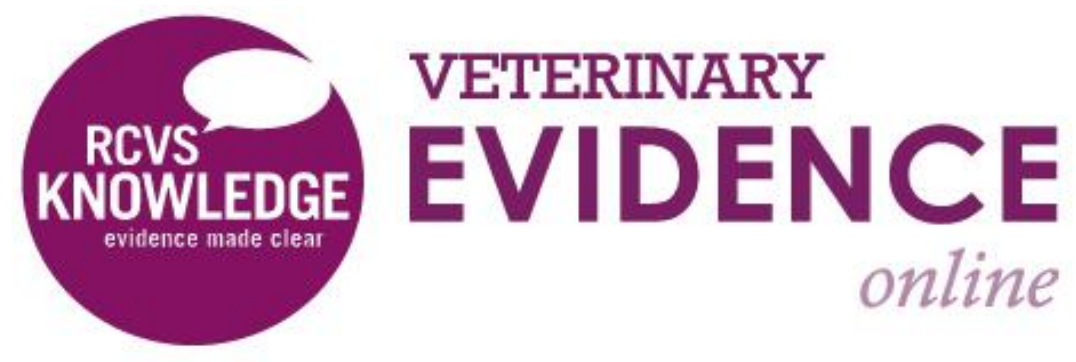

\title{
No evidence that therapeutic systemic corticosteroid administration is associated with laminitis in adult horses without underlying endocrine or severe systemic disease.
}

\section{A Knowledge Summary by}

Catherine McGowan BVSc MACVSc DEIM DipECEIM PhD FHEA MRCVS ${ }^{1^{*}}$ Daniel Cooper BVSC MRCVS ${ }^{2}$ Joanne Ireland BVMS PhD CertAVP(EM) MRCVS ${ }^{3}$

\footnotetext{
${ }^{1}$ University of Liverpool

${ }^{2}$ Clent Hills Equine LLP

3 Animal Health Trust

Corresponding Author (c.m.mcgowan@liv.ac.uk)
}

ISSN: 2396-9776

Published: 25 Jan 2016

in: Vol 1, Issue 1

DOI: http://dx.doi.org/10.18849/ve.v1i1.12.g19 


\section{Clinical bottom line}

- There is currently no conclusive evidence to support a causal association between therapeutic systemic corticosteroid administration and the development of laminitis in healthy adult horses/ponies.

- There is weak evidence of an association between administration of multiple dos- es of systemic corticosteroid and the onset of laminitis in adult horses/ponies with underlying endocrine disorders or severe systemic disease.

\section{Question}

In reported cases of iatrogenic laminitis in adult horses and ponies, is therapeutic administration of systemic corticosteroid associated with the onset of laminitis?

\section{Clinical scenario}

Horses have been reported to develop laminitis following therapeutic systemic corticosteroid administration and the risk of laminitis induced by administration of exogenous glucocorticoids remains a contentious issue in equine medicine. Previously the lack of reported adverse reactions to corticosteroids has been cited as evidence to suggest no association with laminitis. Additionally, many studies investigating the use of corticosteroids in treatment of various conditions (such as recurrent airway obstruction and musculoskeletal disorders) have not observed induction of laminitis.

It has been suspected that the development of laminitis following corticosteroid therapy is more likely in horses with an underlying disease that causes laminitis, specifically, Systemic Inflammatory Response Syndrome (SIRS) or severe systemic disease and endocrine disease. Johnson et al suggest that most widely recognised form of endocrinopathic laminitis occurs in association with steroid administration and that use of corticosteroids must be measured against the well-recognised risk of complicating laminitis (Johnson et al 2004). Johnson et al also state the likelihood of laminitis appears to be greater with the more potent agents such as triamcinolone laminitis (Johnson et al 2004), while an earlier review suggests the association with laminitis has not been reported for use of prednisone or prednisolone (Johnson et al 2002).

Early in vitro research demonstrated corticosteroid potentiation of the vasoconstrictor actions of catecholamines and serotonin, suggesting the resulting venous obstruction on the hoof may cause laminitis (Eyre \& Elmes 1980). Skin perfusion was decreased in a study using six days of daily dexamethasone and the authors suggested perfusion to the hoof may also be reduced, increasing the risk of laminitis (Cornelisse et al 2006). Following a standard overnight dexamethasone suppression test, non-obese ponies with a history of prior laminitis showed elevated insulin concentration and exaggerated production of insulin in response to corticosteroids compared to control ponies (Bailey et al 2007). After a single administration of triamcinolone, one study reported a prolonged period ( $3-4$ days) of hyperglycaemia, hyperinsulinaemia and hypertriglyceridaemia (French et al 2000). Additionally, four of the five horses in this study developed laminar rings without clinical laminitis (French et al 2000). In a small cross-over study, healthy horses demonstrated marked insulin resistance following alternate day dexamethasone administration for three weeks (Tiley et al 2007; Tiley et al 2008). Insulin resistance is associated with a predisposition to laminitis 
(McGowan 2008); therefore it is possible that glucocorticoid-induced decrease in insulin sensitivity may increase the risk for development of laminitis.

Although these studies demonstrate pathophysiological effects of exogenous steroid administration which offer plausible mechanisms by which corticosteroids may induce laminitis, particularly in those animals with existing predisposing factors, they do not provide sufficient evidence to support the hypothesis of increased risk of laminitis associated with the use of steroids in clinical practice. Therefore, this knowledge summary aimed to identify cases of iatrogenic equine laminitis following systemic administration of corticosteroids and to appraise the evidence linking corticosteroid administration and laminitis onset.

\section{The evidence}

Thirteen publications, reporting a total of 40 iatrogenic cases of laminitis following systemic corticosteroid administration, were identified in the literature searches (summarised in Table 1). These comprised six single case reports, three case series, one non-randomised clinical trial of dexamethasone for the treatment of chronic respiratory disorders, a database of adverse drug events, a journalistic style anecdotal case report and a court case transcript. Included publications were of level 4 (case series) or level 5 (mechanism-based reasoning) (OCEBM Levels of Evidence Working Group). Only one observational study aimed to evaluate the prevalence of laminitis amongst horses treated with triamcinolone (McCluskey \& Kavenagh 2004). No experimental studies investigating the frequency of laminitis following therapeutic corticosteroid administration were identified.

Three publications (including eight cases) did not report information regarding the type of corticosteroid administered (Cripps \& Eustace 1999; Lose 1980; Slater et al 1995). Of the 32 cases of iatrogenic laminitis reported in the other included publications, $53 \%(n=17)$ were reported to occur following administration of triamcinolone (Cohen \& Carter 1992; McCluskey \& Kavenagh 2004; Ryu et al 2004; U.S. FDA), 34\% $(n=11)$ were reported to occur following administration of dexamethasone (Fredrick \& Kehl 2000; Humber et al 1991; Muyelle \& Oyaert 1973; Vandenabeele et al 2004; U.S. FDA), 3\% ( $n=1)$ occurred following administration of methylprednisolone (U.S. FDA) and $3 \%(n=1)$ occurred following administration of betamethasone (U.S. FDA). Two further cases were reported to develop laminitis following the administration of more than one corticosteroid (Anon 2005; Winfield et al 2013).

Ten publications (including 14 cases) reported some information regarding duration of treatment or number of corticosteroid treatments, of which $79 \%$ of cases $(n=11 / 14)$ developed laminitis following multiple doses of corticosteroid (Cohen \& Carter 1992; Fredrick \& Kehl 2000; Humber et al 1991; Muyelle \& Oyaert 1973; Ryu et al 2004; Vandenabeele et al 2004; Winfield et al 2013). The remaining $21 \%$ of cases ( $n=3 / 14$ ) developed laminitis following administration of corticosteroid on a single occasion; however two of these cases received multiple intra-articular doses of unknown corticosteroid (Lose 1980) or triamcinolone (McCluskey \& Kavenagh 2004) and the other case received multiple doses of dexamethasone and possibly multiple intra-articular doses of triamcinolone (Anon 2005). 


\begin{tabular}{|c|c|}
\hline \multicolumn{2}{|l|}{ Muylle (1973) } \\
\hline Population: & $\begin{array}{l}10 \text { normal horses and } 15 \text { horses with chronic respiratory disorders. } \\
\text { Respiratory cases referred to veterinary medical teaching hospital, } \\
\text { Ghent, Belgium }\end{array}$ \\
\hline Sample size: & $\begin{array}{l}\text { - } 25 \text { horses (predominantly Standardbreds and hunter type) } \\
\text { - } 15 \text { horses administered dexamethasone } \\
\text { - } \quad \text { Study population included } 2 \text { iatrogenic laminitis cases }\end{array}$ \\
\hline Intervention details: & $\begin{array}{l}\text { Intramuscular administration of dexamethasone } 25 \mathrm{mg} \text { on alternate } \\
\text { days for } 4-6 \text { treatments until remission of clinical signs achieved. }\end{array}$ \\
\hline Study design: & $\begin{array}{l}\text { Non-randomised, controlled clinical trial of dexamethasone for the } \\
\text { treatment of chronic respiratory disorders }\end{array}$ \\
\hline Outcome studied: & $\begin{array}{l}\text { Objective assessment: Lung function test results in horses with } \\
\text { chronic respiratory disorders compared to healthy controls and } \\
\text { following dexamethasone treatment. }\end{array}$ \\
\hline $\begin{array}{l}\text { Main findings: } \\
\text { (relevant to PICO question): }\end{array}$ & $\begin{array}{l}\text { - } 2 \text { of the } 15 \text { dexamethasone-treated horses developed } \\
\text { laminitis 'a short time after discharge'. } \\
\text { - } 1 \text { of the } 2 \text { laminitis cases was treated successfully }\end{array}$ \\
\hline Limitations: & $\begin{array}{l}\text { Primary objective of the study was investigation of lung } \\
\text { function in response to dexamethasone treatment for } \\
\text { chronic respiratory disease. } \\
\text { - No clinical details presented for iatrogenic cases and } \\
\text { corticosteroid administration not evaluated as risk factor for } \\
\text { development of laminitis. } \\
\text { - Lack of temporal information precludes assessment of } \\
\text { association between corticosteroids and onset of laminitis. }\end{array}$ \\
\hline
\end{tabular}

\begin{tabular}{|r|l|}
\hline \multicolumn{2}{|l|}{ Lose (1980) } \\
\hline Population: & $\begin{array}{l}\text { 2 year old Standardbred colt attended by a first opinion equine } \\
\text { hospital, Pennsylvania, USA }\end{array}$ \\
\hline Sample size: & 1 \\
\hline Intervention details: & $\begin{array}{l}\text { Single intra-articular administration both tarsi. Corticosteroid and } \\
\text { dose not reported. }\end{array}$ \\
\hline Study design: & Case report \\
\hline Outcome studied: & $\begin{array}{l}\text { Objective assessment: Description of treatment of single iatrogenic } \\
\text { laminitis case }\end{array}$ \\
\hline Main findings: & $\begin{array}{l}\text { Onset of laminitis affecting all four feet 8 days after } \\
\text { corticosteroid administration. Confirmed by radiography - } \\
\text { rotation evident in all four feet (right fore most severely } \\
\text { affected). }\end{array}$ \\
& $\begin{array}{l}\text { No clinical details or information regarding diagnostic testing } \\
\text { for underlying disease(s) reported. }\end{array}$ \\
\hline
\end{tabular}




\begin{tabular}{|l|l|}
\hline Limitations: & - $\begin{array}{l}\text { Single case report, with primary focus on treatments used } \\
\text { for laminitis. }\end{array}$ \\
& $\begin{array}{l}\text { Provides weak evidence of association between therapeutic } \\
\text { administration of corticosteroids and onset of laminitis in a } \\
\text { single horse. No details presented regarding presence or } \\
\text { absence of underlying disease. }\end{array}$ \\
\hline
\end{tabular}

\begin{tabular}{|c|c|}
\hline \multicolumn{2}{|l|}{ Humber (1991) } \\
\hline Population: & $\begin{array}{l}2 \text { horses with immune-mediated thrombocytopaenia referred to } \\
\text { veterinary medical teaching hospital, Pennsylvania, USA }\end{array}$ \\
\hline Sample size: & 1 iatrogenic laminitis case ( 8 year old Thoroughbred mare) \\
\hline Intervention details: & $\begin{array}{l}\text { Intravenous administration of dexamethasone. } 0.16 \mathrm{mg} / \mathrm{kg} \text { every } 12 \\
\text { hours for } 3 \text { days }\end{array}$ \\
\hline Study design: & Case report \\
\hline Outcome studied: & $\begin{array}{l}\text { Objective assessment: Description of clinical presentation and } \\
\text { treatment of immune-mediated thrombocytopaenia }\end{array}$ \\
\hline $\begin{array}{l}\text { Main findings: } \\
\text { (relevant to PICO question): }\end{array}$ & $\begin{array}{l}\text { - Onset of mild laminitis affecting all four feet } 10 \text { days after } \\
\text { cessation of corticosteroid administration. Confirmed by } \\
\text { post mortem examination - slight displacement of the third } \\
\text { phalanx in both forelimbs. } \\
\text { - Affected horse had evidence of systemic disease } \\
\text { (progressive epistaxis, ecchymotic haemorrhages involving } \\
\text { the oral mucous membranes, hyphema, petechial } \\
\text { haemorrhages on the sclerae, and nasal and vaginal mucous } \\
\text { membranes). The horse also had swellings in the mid cervical } \\
\text { region over the jugular veins. Mucous membranes were } \\
\text { pale.Mild neutrophilic leucocytosis, anaemia, } \\
\text { hypoproteinaemic and thrombocytopenic. Blood in faeces. }\end{array}$ \\
\hline Limitations: & $\begin{array}{l}\text { - Single case report. } \\
\text { - Provides weak evidence of association between therapeutic } \\
\text { administration of systemic corticosteroids and onset of } \\
\text { laminitis in a single horse with severe systemic disease. }\end{array}$ \\
\hline
\end{tabular}

\begin{tabular}{|r|l|}
\hline \multicolumn{2}{|l|}{ Cohen (1992) } \\
\hline Population: & $\begin{array}{l}10 \text { year old Quarter Horse gelding referred to veterinary medical } \\
\text { teaching hospital, Texas, USA }\end{array}$ \\
\hline Sample size: & 1 \\
\hline Intervention details: & $\begin{array}{l}12 \mathrm{mg}(6 \mathrm{ml}) \text { of triamcinolone administered; } 2^{\text {nd }} \text { treatment } 3 \text { weeks } \\
\text { later of } 10 \mathrm{mg}(5 \mathrm{ml}) \text { of triamcinolone (injected by owner without } \\
\text { veterinary consult); } 3^{\text {rd }} \text { treatment administered by owner } 7 \text { days } \\
\text { after } 2^{\text {nd }} \text { second treatment }(\text { dose details unknown but suspension } \\
\text { was much stronger }(40 \mathrm{mg} / \mathrm{ml}) \text { ). }\end{array}$ \\
\hline Study design: & Case report \\
\hline Outcome studied: & $\begin{array}{l}\text { Objective assessment: Description of clinical presentation and } \\
\text { treatment of steroid hepatopathy }\end{array}$ \\
\hline
\end{tabular}




\begin{tabular}{|c|c|}
\hline $\begin{array}{l}\text { Main findings: } \\
\text { (relevant to PICO question): }\end{array}$ & $\begin{array}{l}\text { Onset of bilateral forelimb laminitis } 6 \text { weeks and } 6 \text { days after } \\
\text { first corticosteroid administration ( } 2 \text { weeks and } 6 \text { days after } \\
\text { last). Confirmed by radiography - rotation evident in both } \\
\text { fore feet. } \\
\text { - Affected horse had evidence of severe concurrent disease } \\
\text { (hepatopathy and hyperadrenocorticism). }\end{array}$ \\
\hline Limitations: & $\begin{array}{l}\text { - Single case report. } \\
\text { - Laminitis developed approximately } 3 \text { weeks following } \\
\text { cessation of corticosteroid treatment, which does not } \\
\text { convincingly support a causal association. }\end{array}$ \\
\hline
\end{tabular}

\begin{tabular}{|c|c|}
\hline Slater (1995) & \\
\hline Population: & $\begin{array}{l}\text { Laminitis cases attended by } 7 \text { private practices and referred to } \\
\text { veterinary medical teaching hospital, Texas, USA }\end{array}$ \\
\hline Sample size: & $\begin{array}{l}\text { - } 108 \text { laminitis cases } \\
\text { - } \quad \text { Study population included } 3 \text { iatrogenic laminitis cases }\end{array}$ \\
\hline Intervention details: & $\begin{array}{l}\text { No details regarding corticosteroid administered, dose or duration of } \\
\text { treatment. } 3 \text { cases in series reported to have received steroids 'just } \\
\text { prior to the onset of laminitis' with no time frame stated. }\end{array}$ \\
\hline Study design: & Case control study \\
\hline Outcome studied: & $\begin{array}{l}\text { Objective assessment: Horse level and clinical factors associated } \\
\text { acute or chronic laminitis and description of treatments } \\
\text { administered }\end{array}$ \\
\hline $\begin{array}{l}\text { Main findings: } \\
\text { (relevant to PICO question): }\end{array}$ & $\begin{array}{l}3 \text { of } 108 \text { laminitis cases had a history of corticosteroid administration } \\
\text { prior to the onset of clinical signs. }\end{array}$ \\
\hline Limitations: & $\begin{array}{l}\text { - No clinical details presented for iatrogenic cases and } \\
\text { corticosteroid administration not evaluated as risk factor for } \\
\text { development of laminitis. } \\
\text { - Lack of temporal information precludes assessment of } \\
\text { association between corticosteroids and onset of laminitis. }\end{array}$ \\
\hline
\end{tabular}

\begin{tabular}{|c|c|}
\hline Cripps (1999) & \\
\hline Population: & $\begin{array}{l}\text { Laminitis cases referred to a specialist equine laminitis referral } \\
\text { centre, England, UK }\end{array}$ \\
\hline Sample size: & $\begin{array}{l}\text { - } 216 \text { laminitis cases, of which } 211 \text { included in study } \\
\text { - } \quad \text { Study population included } 4 \text { iatrogenic laminitis cases }\end{array}$ \\
\hline Intervention details: & $\begin{array}{l}\text { No details regarding corticosteroid administered, dose or duration of } \\
\text { treatment. } 4 \text { laminitis cases in series reported as iatrogenic } \\
\text { 'following injections of corticosteroids' with no time frame stated. }\end{array}$ \\
\hline Study design: & Case series - retrospective review of clinical records \\
\hline Outcome studied: & $\begin{array}{l}\text { Objective assessment: Horse level and clinical factors associated } \\
\text { with outcome of treatment for laminitis (successful versus } \\
\text { unsuccessful treatment) }\end{array}$ \\
\hline
\end{tabular}




\begin{tabular}{|r|r|r|}
\hline $\begin{array}{r}\text { Main findings: } \\
\text { (relevant to PICO question): }\end{array}$ & $\begin{array}{c}\text { 4 laminitis cases in series reported as iatrogenic. } 2 \text { of the } 4 \text { iatrogenic } \\
\text { cases were treated successfully. }\end{array}$ \\
\hline Limitations: & $\begin{array}{l}\text { Primary objective of the study was investigation of clinical } \\
\text { parameters associated with outcome of treatment for }\end{array}$ \\
& $\begin{aligned} \text { laminitis. } \\
\text { - No clinical details presented for iatrogenic cases and } \\
\text { corticosteroid administration not evaluated as risk factor for } \\
\text { development of laminitis. } \\
\text { - Lack of temporal information precludes assessment of } \\
\text { association between corticosteroids and onset of laminitis. }\end{aligned}$ \\
\hline
\end{tabular}

\begin{tabular}{|c|c|}
\hline \multicolumn{2}{|l|}{ Frederick $(2000)$} \\
\hline \multicolumn{2}{|c|}{$\begin{array}{l}\text { Frederick ( } 2000) \\
\qquad \text { Population: } \\
23 \text { year old American Saddlebred gelding, USA }\end{array}$} \\
\hline Sample size: & 1 \\
\hline Intervention details: & $\begin{array}{l}\text { Single bolus injection of Naquasone (trichlormethiazide } 10 \mathrm{mg} \text { and } \\
\text { dexamethasone acetate } 0.55 \mathrm{mg} / \mathrm{ml} \text { ) followed by } 4 \text { days oral } \\
\text { administration of Naquasone tablets. Dose not reported. }\end{array}$ \\
\hline Study design: & Case report \\
\hline Outcome studied: & $\begin{array}{l}\text { Subjective assessment: Owner and veterinary surgeon account of } \\
\text { single iatrogenic laminitis case }\end{array}$ \\
\hline \multirow[t]{2}{*}{$\begin{array}{r}\text { Main findings: } \\
\text { (relevant to PICO question): } \\
\text { Limitations: }\end{array}$} & $\begin{array}{l}\text { - Onset of laminitis affecting all four feet on } 4^{\text {th }} \text { day of } \\
\text { corticosteroid administration. Confirmed by radiography - } \\
\text { rotation evident in both fore feet. } \\
\text { - Gelding was obese with regional adiposity (cresty neck). } \\
\text { - Diagnostic tests for hypothyroidism and PPID inconclusive } \\
\text { (neither specific tests nor results reported). }\end{array}$ \\
\hline & $\begin{array}{l}\text { - Very low quality non-peer reviewed single case report in } \\
\text { journalistic style. } \\
\text { - Provides very weak evidence of association between } \\
\text { therapeutic administration of systemic corticosteroids and } \\
\text { onset of laminitis in a single aged horse with clinical signs of } \\
\text { underlying endocrine disease }\end{array}$ \\
\hline
\end{tabular}




\begin{tabular}{|c|c|}
\hline \multicolumn{2}{|l|}{ Ryu (2004) } \\
\hline \multicolumn{2}{|r|}{3 year old Thoroughbred filly referred to equine hospital, Korea } \\
\hline Sample size: & 1 \\
\hline Intervention details: & $\begin{array}{l}\text { Intramuscular administration of triamcinolone acetonide } 20 \mathrm{mg} \text { once } \\
\text { daily for } 10 \text { consecutive days }\end{array}$ \\
\hline Study design: & Case report \\
\hline Outcome studied: & $\begin{array}{l}\text { Objective assessment: Description of clinical presentation and } \\
\text { treatment of single iatrogenic laminitis case }\end{array}$ \\
\hline $\begin{array}{l}\text { Main findings: } \\
\text { (relevant to PICO question): }\end{array}$ & $\begin{array}{l}\text { - Onset of bilateral forelimb laminitis } 33 \text { days after first } \\
\text { corticosteroid administration ( } 23 \text { days after last). } \\
\text { - Confirmed by radiography - severe rotation evident with } \\
\text { eventual sole penetration. } \\
\text { Initially referred } 25 \text { days after first corticosteroid } \\
\text { administration for haematuria and steroid hepatopathy with } \\
\text { weight loss, vaginal hyperaemia, leukopenia and polyuria. } \\
\text { - Affected horse had evidence of systemic disease (pyrexia, } \\
\text { tachycardia, tachypnoea), congested mucous membranes, } \\
\text { thrombophlebitis and neutrophilia). }\end{array}$ \\
\hline Limitations: & $\begin{array}{l}\text { - Single case report. } \\
\text { - Laminitis developed } 23 \text { days following cessation of } \\
\text { corticosteroid treatment, which does not convincingly } \\
\text { support a causal association. }\end{array}$ \\
\hline
\end{tabular}

McCluskey (2004)

\begin{tabular}{|r|r|}
\hline Population: & $\begin{array}{l}\text { Adult horses treated with triamcinolone in an equine ambulatory } \\
\text { practice, Victoria, Australia }\end{array}$ \\
\hline Sample size: & $\begin{array}{r}132 \text { horses treated with triamcinolone (total } 205 \text { triamcinolone } \\
\text { treatments). } \\
\text { Study population included } 1 \text { iatrogenic laminitis case (7 year } \\
\text { old Thoroughbred gelding) }\end{array}$ \\
\hline Intervention details: & $\begin{array}{r}\text { Intra-articular administration of triamcinolone acetonide } 10 \text { mg into } 4 \\
\text { joints (40 mg total dose) }\end{array}$ \\
\hline Study design: & Case series - retrospective review of clinical records \\
\hline Outcome studied: & $\begin{array}{l}\text { Objective assessment: Prevalence of laminitis in adult horses treated } \\
\text { with triamcinolone }\end{array}$ \\
\hline Main findings: & $\begin{array}{l}\text { Single horse (n=1/132) developed laminitis one week after } \\
\text { corticosteroid treatment. }\end{array}$ \\
\hline Limitations: & $\begin{array}{l}\text { latrogenic laminitis case reported to have previous episode of } \\
\text { laminitis 7 months prior. No clinical details or information } \\
\text { regarding diagnostic testing for underlying disease(s) } \\
\text { reported. }\end{array}$ \\
\hline $\begin{array}{l}\text { Single case described within a case series with very limited } \\
\text { clinical data reported. }\end{array}$ \\
$\begin{array}{r}\text { Provides weak evidence of association between therapeutic } \\
\text { administration of systemic corticosteroids and onset of } \\
\text { laminitis in a single horse with previous history of laminitis. }\end{array}$ \\
\hline
\end{tabular}




\begin{tabular}{|c|c|}
\hline \multicolumn{2}{|l|}{ Vandenabeele (2004) } \\
\hline Population: & $\begin{array}{l}\text { Pemphigus foliaceus cases referred to a veterinary medical teaching } \\
\text { hospital, California, USA }\end{array}$ \\
\hline Sample size: & $\begin{array}{l}\text { - } 20 \text { pemphigus foliaceus cases } \\
\text { - Study population included } 4 \text { iatrogenic laminitis cases: } 2 \text { year } \\
\text { old Quarter Horse filly; } 3.5 \text { year old Quarter Horse filly; } 4 \\
\text { year old Standardbred mare; } 5 \text { year old Quarter Horse } \\
\text { gelding }\end{array}$ \\
\hline Intervention details: & $\begin{array}{l}\text { - Oral dexamethasone } 0.05-0.1 \mathrm{mg} / \mathrm{kg} \text { per day ( } \mathrm{n}=13) \text {; Oral } \\
\mathrm{prednisone} 1-2 \mathrm{mg} / \mathrm{kg} \text { per day }(\mathrm{n}=3) \text {. Oral prednisolone } 1-2 \\
\mathrm{mg} / \mathrm{kg} \text { per day }(\mathrm{n}=4) \\
\text { Duration of treatment not reported; however alternate-day } \\
\text { dosing of corticosteroids was implemented when lesions } \\
\text { were in remission (10-14 days of treatment) }\end{array}$ \\
\hline Study design: & Case series - retrospective review of clinical records \\
\hline Outcome studied: & $\begin{array}{l}\text { Objective assessment: Description of clinical presentation and } \\
\text { treatment of pemphigus foliaceus cases }\end{array}$ \\
\hline $\begin{array}{l}\text { Main findings: } \\
\text { (relevant to PICO question): }\end{array}$ & $\begin{array}{l}\text { - } 4 \text { iatrogenic acute laminitis cases reported following } \\
\text { dexamethasone treatment. } \\
\text { - } 3 \text { cases euthanased due to laminitis. } 4^{\text {th }} \text { case treated } \\
\text { successfully. } \\
\text { - Serum albumin measured in } 2 \text { of the } 3 \text { non-surviving cases - } \\
\text { both had hypoalbuminaemia. } \\
\text { - Time frame of onset of laminitis relative to dexamethasone } \\
\text { not reported. }\end{array}$ \\
\hline Limitations: & $\begin{array}{l}\text { - } 4 \text { laminitis cases described with very limited clinical data } \\
\text { reported. } \\
\text { - Lack of temporal information precludes assessment of } \\
\text { association between corticosteroids and onset of laminitis. }\end{array}$ \\
\hline
\end{tabular}

\begin{tabular}{|c|c|}
\hline Anon (2005) & \\
\hline Population: & 14 year old mare, England, UK \\
\hline Sample size: & 1 \\
\hline Intervention details: & $\begin{array}{l}\text { - Dosage and nature of corticosteroids administered } \\
\text { contested ad unclear. } \\
\text { - Possible intra-articular administration of triamcinolone } \\
\text { acetonide both tarsi ( } 1 \times 80 \mathrm{mg} / 2 \mathrm{ml} \text { in each joint) OR intra- } \\
\text { articular administration of dexamethasone both tarsi ( } 1 \times \\
4 \mathrm{mg} \text { in each joint) } \\
\text { - Multiple intra-muscular injections into back cumulatively of } \\
20 \mathrm{mg} \text { of dexamethasone }\end{array}$ \\
\hline
\end{tabular}




\begin{tabular}{|c|c|}
\hline Study design: & Court case transcript \\
\hline Outcome studied: & $\begin{array}{l}\text { Subjective assessment: Transcript of summary of evidence given } \\
\text { during court case }\end{array}$ \\
\hline $\begin{array}{l}\text { Main findings: } \\
\text { (relevant to PICO question): }\end{array}$ & $\begin{array}{l}\text { - Laminitis diagnosed } 11 \text { days after corticosteroid treatment. } \\
\text { - } \quad \text { Received intra-articular administration of triamcinolone } \\
\text { right fore fetlock } 4 \text { years previously - dose not reported - no } \\
\text { adverse events. Received multiple intra-articular and intra- } \\
\text { muscular injections of dexamethasone } 2 \text { years - dose not } \\
\text { reported - no adverse events. }\end{array}$ \\
\hline Limitations: & $\begin{array}{l}\text { - No clinical details or diagnostic information reported. } \\
\text { - Court case assumes causal association between } \\
\text { administration of corticosteroids and onset of laminitis. } \\
\text { Provides weak evidence of association between therapeutic } \\
\text { administration of large doses of corticosteroids and onset of } \\
\text { laminitis in a single horse. No details presented regarding } \\
\text { presence or absence of underlying disease. }\end{array}$ \\
\hline
\end{tabular}

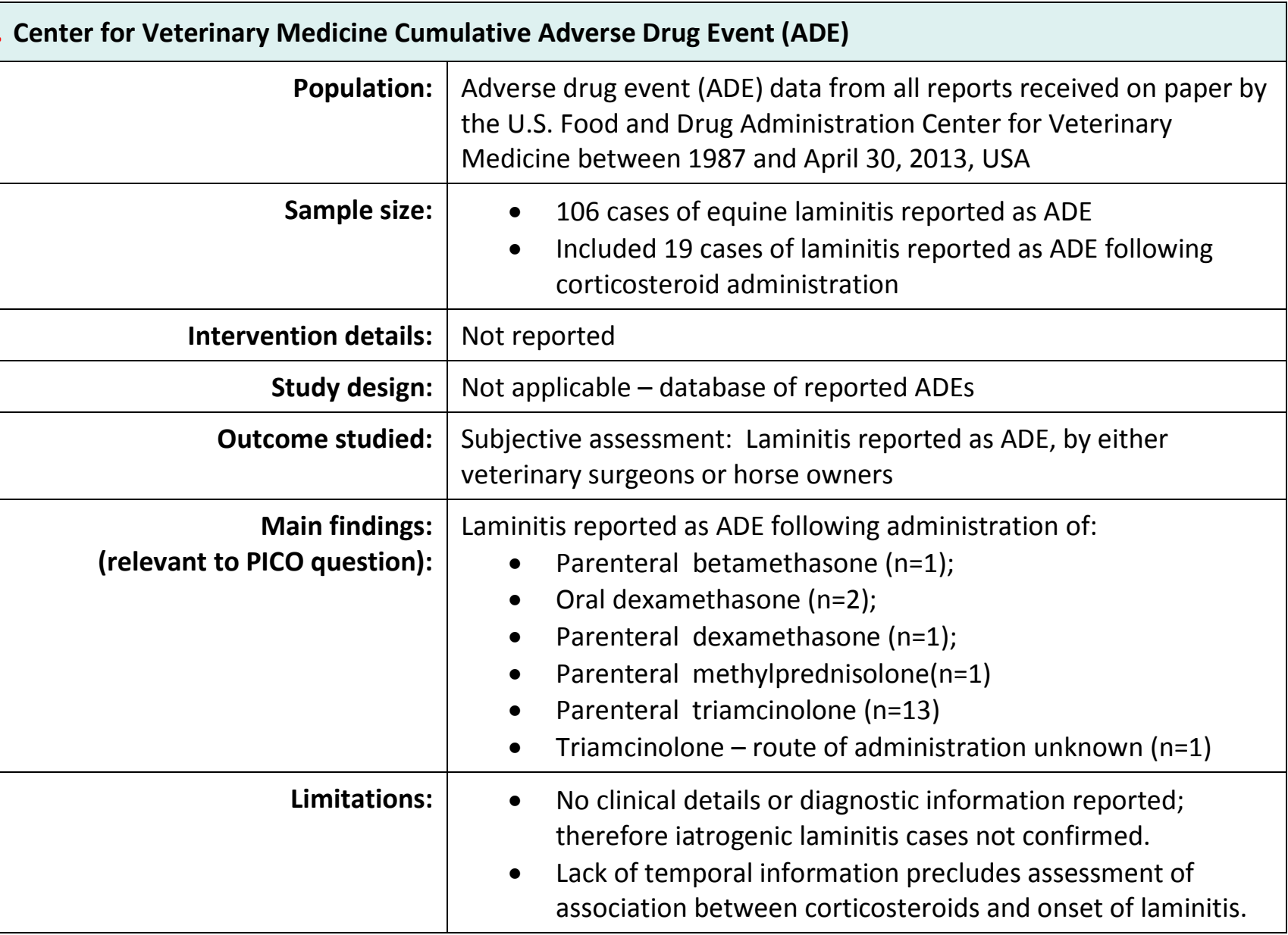




\begin{tabular}{|c|c|}
\hline \multicolumn{2}{|l|}{ Winfield (2013) } \\
\hline Population: & $\begin{array}{l}9 \text { year old Welsh pony stallion referred to a veterinary medical } \\
\text { teaching hospital, California, USA }\end{array}$ \\
\hline Sample size: & 1 \\
\hline Intervention details: & $\begin{array}{l}\text { Intramuscular administration of dexamethasone }(0.05 \mathrm{mg} / \mathrm{kg} \text { once } \\
\text { daily for } 3 \text { consecutive days, followed by oral prednisolone }(0.5-1.0 \\
\mathrm{mg} / \mathrm{kg} \text { once daily; plus topical administration of } 0.015 \% \\
\text { triamcinolone acetonide spray }\end{array}$ \\
\hline Study design: & Case report. \\
\hline Outcome studied: & $\begin{array}{l}\text { Objective assessment: Description of clinical presentation and } \\
\text { treatment of a single pemphigus vulgaris case }\end{array}$ \\
\hline $\begin{array}{l}\text { Main findings: } \\
\text { (relevant to PICO question): }\end{array}$ & $\begin{array}{l}\text { - Onset of laminitis affecting all four feet within } 4 \text { months } \\
\text { following initiation of corticosteroid administration (possibly } \\
\text { after } 6 \text { weeks of treatment based on Figure } 55 \text { legend in } \\
\text { supplementary information). Initial foot soreness developed } \\
\text { as prednisolone dose was increased to } 0.8 \mathrm{mg} / \mathrm{kg} / \mathrm{day} \text {. } \\
\text { Confirmed by post mortem examination - rotation and hoof } \\
\text { wall separation in all four feet. } \\
\text { - In addition to pemphigus vulgaris, affected pony had } \\
\text { evidence of chronic inflammation and systemic illness, } \\
\text { considered by the authors to be contributing factors in the } \\
\text { development of laminitis. }\end{array}$ \\
\hline Limitations: & $\begin{array}{l}\text { Primary objective of the report was to describe the clinical, } \\
\text { histological and immunological findings of a case of } \\
\text { pemphigus vulgaris. } \\
\text { - Lack of accurate temporal information precludes assessment } \\
\text { of association between corticosteroids and onset of } \\
\text { laminitis. }\end{array}$ \\
\hline
\end{tabular}




\section{Appraisal, application and reflection}

The aim of this knowledge summary was to critically appraise published evidence of iatrogenic equine laminitis following systemic administration of corticosteroids. It was beyond the scope of this review to evaluate the extensive published literature reporting on the therapeutic use of systemic corticosteroids where laminitis has not been observed or reported as an adverse event following treatment.

The 13 included publications were predominantly descriptive studies and provided low level evidence pertaining to the potential association between therapeutic administration of systemic corticosteroid and the onset of laminitis (OCEBM Levels of Evidence Working Group). No studies of an appropriate design to determine the incidence of laminitis following corticosteroid treatment or evaluate temporal relationships between corticosteroid administration and the onset of laminitis (i.e. longitudinal analytical studies) were identified.

The only observational study investigating iatrogenic laminitis following treatment with triamcinolone reported a prevalence of $0.8 \%$ ( $n=1 / 132 ; 95 \%$ confidence interval $0-2.2 \%$ ) (McCluskey

\& Kavenagh 2004). In the same study, three other cases of laminitis were reported, of which two were diagnosed with laminitis prior to triamcinolone but did not develop laminitis subsequent to its use. Therefore, laminitis following triamcinolone administration was observed in $33 \%$ of horses with a previous history of laminitis $(n=1 / 3)$. The third horse developed laminitis 18 months after triamcinolone therapy as a result of post foaling toxaemic metritis (McCluskey \& Kavenagh 2004). Of 106 equine laminitis cases reported as adverse drug events over a 26 year period, 18\% ( $n=19)$ were attributed to corticosteroid treatment, whereas $35 \%$ of cases $(n=37)$ were attributed to administration of anthelmintics and $32 \%(n=34)$ were reported following treatment with antibiotics or antiprotozoals (U.S. FDA).

Only eight publications (each reporting a single case of iatrogenic laminitis) provided information regarding the time of onset of laminitis relative to corticosteroid administration (Anon 2005; Cohen \& Carter 1992; Fredrick \& Kehl 2000; Humber et al 1991; Lose 1980; McCluskey \& Kavenagh 2004; Ryu et al 2004; Winfield et al 2013). One of the eight cases occurred during corticosteroid treatment (onset of laminitis reported on day 4 of a 5 day course) (Fredrick \& Kehl 2000). Onset or diagnosis of laminitis was reported to occur 7 days (McCluskey \& Kavenagh 2004), 8 days (Lose 1980), 10 days (Humber et al 1991), 11 days (Anon 2005), 20 days (Cohen \& Carter 1992) and 23 days (Ryu et al 2004) after cessation of corticosteroid treatment. Two of these cases, one with severe systemic disease (Ryu et al 2004) and one with hepatopathy and hyperadrenocorticism (Cohen \& Carter 1992), occurred three weeks after the last dose of corticosteroid. The longer the period of time between drug administration and disease onset, the less likely the drug was a contributing factor in the aetiology due to its reduced efficacy in the body as time passes (Harkins et al 1993). The time frame for both these two cases appears to be too long to suggest a direct causal association, especially as in both cases laminitis occurred over a week after the onset of clinical signs of systemic disease. In the remaining case, laminitis was reported to have occurred within 4 months of commencing corticosteroid treatment (Winfield et al 2013).

Seven publications provided diagnostic information, of which five (representing eight cases) reported confirmation of diagnosis via radiography (Cohen \& Carter 1992; Cripps \& Eustace 1999; Fredrick \& Kehl 2000; Lose 1980; Ryu et al 2004) and two (representing two cases) reported confirmation via gross pathology at post mortem examination (Humber et al 1991; Winfield et al 2013). Few included studies provided detailed clinical information regarding the presentation and severity of laminitis. Two epidemiological studies of laminitis (Cripps \& Eustace 1999; Slater et al 1995) did not include any clinical information pertaining to iatrogenic laminitis cases, and reported only that animals had received corticosteroids prior to the onset of laminitis, while the Center for Veterinary Medicine Cumulative Adverse Drug Event (ADE) Summaries Report (U.S. FDA) provided no details other than the type of corticosteroid administered prior to laminitis. Where reported, laminitis most frequently affected all four feet $(67 \%$, 
$\mathrm{n}=4 / 6$ ) (Fredrick \& Kehl 2000; Humber et al 1991; Lose 1980; Winfield et al 2013), and a further two cases $(33 \%, n=2 / 6)$ (Cohen \& Carter 1992; Ryu et al 2004) developed bilateral forelimb laminitis. Outcome was reported for 18 cases, of which $50 \%(n=9)$ were reported to have survived/recovered, although two cases were reported to have been retired from their previous athletic use due to laminitis (McCluskey \& Kavenagh 2004; Ryu et al 2004). One non-surviving case was euthanased due to progression of pemphigus vulgaris rather than laminitis (Winfield et al 2013) and the reason for euthanasia was unclear in one further nonsurviving case (Humber et al 1991).

Diagnostic evaluation of underlying disease(s) was infrequently reported. Of the five laminitis cases occurring during treatment or within two weeks of corticosteroid administration, one horse was obese with marked regional adiposity, suggestive of equine metabolic syndrome (Fredrick \& Kehl 2000); one horse had a previous history of laminitis (McCluskey \& Kavenagh 2004) and one had severe systemic disease (Humber et al 1991). A further three cases had evidence of severe systemic disease (Cohen \& Carter 1992; Ryu et al 2004; Winfield et al 2013). Of four iatrogenic laminitis cases reported amongst horses treated with dexamethasone for pemphigus foliaceus, two non-surviving cases for which serum albumin was measured were hypoalbuminaemic (Vandenabeele et al 2004).

In conclusion, no studies that sought to investigate a potential causal association between therapeutic corticosteroid administration and laminitis were identified and there is currently insufficient evidence to support such an association in healthy adult horses. There is weak evidence of an association between administration of multiple doses of systemic corticosteroid and the onset of laminitis in adult horses with underlying endocrine disorders or severe systemic disease. Therefore, underlying diseases predisposing to laminitis should be considered prior to administration of corticosteroids, particularly where multiple or large doses are indicated. However, this knowledge summary has highlighted a paucity of information on iatrogenic laminitis and a well-designed cohort study is required to quantify the apparently small risk of iatrogenic laminitis following therapeutic administration of systemic corticosteroid.

\section{Methodology Section}

\begin{tabular}{|c|c|}
\hline \multicolumn{2}{|l|}{ Search Strategy } \\
\hline $\begin{array}{r}\text { Databases searched and dates } \\
\text { covered: }\end{array}$ & $\begin{array}{l}\text { - } \quad \text { PubMed accessed via the NCBI website ( } 1950 \text { - Present) } \\
\text { - Thomson Reuters Web of Science (1898 - Present) } \\
\text { - CAB Abstracts on the CAB Direct interface (1910 - Present) } \\
\text { - SciVerse Scopus ( } 1823 \text { - Present) } \\
\text { - International Veterinary Information Service (IVIS) database } \\
\text { (1997 - Present) } \\
\text { - Further relevant records were identified by the authors via } \\
\text { the bibliographies and reference lists of retrieved } \\
\text { publications and published conference proceedings. }\end{array}$ \\
\hline Search terms: & $\begin{array}{l}\text { (equine or horse* or pony or ponies ) AND (laminitis or laminitic) } \\
\text { AND (corticosteroid* or glucocorticoid* or dexamethasone or dex or } \\
\text { prednisolone or methylprednisolone or triamcinolone or TMC or } \\
\text { betamethasone) }\end{array}$ \\
\hline Dates searches performed: & $26 / 05 / 2015$ and $27 / 05 / 2015$ \\
\hline
\end{tabular}




\section{Exclusion / Inclusion Criteria}

No limitations regarding study design, setting, sample size or study population were imposed.

Exclusion: Non-English language, narrative or non-systematic review articles (or non-systematic reviews published in conference proceedings or as letters/correspondence), unpublished data, pharmacokinetic, in vitro or in vivo experimental studies.

Inclusion: Any reported case of laminitis occurring in an adult horse or pony following the systemic administration of corticosteroid(s).

\begin{tabular}{|c|c|c|c|c|c|c|}
\hline \multicolumn{7}{|c|}{ Search Outcome } \\
\hline Database & $\begin{array}{c}\text { Number } \\
\text { of } \\
\text { results }\end{array}$ & $\begin{array}{l}\text { Excluded - } \\
\text { non- } \\
\text { English } \\
\text { language } \\
\text { publication }\end{array}$ & $\begin{array}{l}\text { Excluded - non- } \\
\text { systematic } \\
\text { review article, } \\
\text { conference } \\
\text { proceeding or } \\
\text { letter }\end{array}$ & $\begin{array}{c}\text { Excluded - } \\
\text { pharmacokinetic } \\
\text { / in vitro / in } \\
\text { vivo } \\
\text { experimental } \\
\text { study }\end{array}$ & $\begin{array}{l}\text { Excluded - did } \\
\text { not answer } \\
\text { PICO question / } \\
\text { no iatrogenic } \\
\text { laminitis } \\
\text { case(s) } \\
\text { reported }\end{array}$ & $\begin{array}{c}\text { Total } \\
\text { relevant } \\
\text { papers }\end{array}$ \\
\hline $\begin{array}{l}\text { NCBI } \\
\text { PubMed }\end{array}$ & 34 & 1 & 10 & 6 & 13 & 4 \\
\hline $\begin{array}{l}\text { Thomson } \\
\text { Reuters Web } \\
\text { of Science }\end{array}$ & 84 & 1 & 31 & 12 & 34 & 6 \\
\hline CAB Direct & 86 & 1 & 44 & 13 & 24 & 4 \\
\hline $\begin{array}{l}\text { SciVerse } \\
\text { Scopus }\end{array}$ & 66 & 5 & 30 & 7 & 19 & 5 \\
\hline $\begin{array}{l}\text { International } \\
\text { Veterinary } \\
\text { Information } \\
\text { Service (IVIS) } \\
\text { database }\end{array}$ & 70 & 0 & 69 & 0 & 1 & 0 \\
\hline $\begin{array}{l}\text { Other } \\
\text { sources }\end{array}$ & 7 & 0 & 1 & 0 & 1 & 5 \\
\hline
\end{tabular}


1. Anon (2005) Philip John Glyn (t/a Priors Farm Equine Veterinary Surgery) v Jane McGarel-Groves, Erik Grandiere, Clinique Veterinaire Equine De Chantilly. Case Number: HQ O3X 01706.[vLex: United Kingdom] [online] Available from: http://high-court-justice.vlex.co.uk/vid/hq-03x-01706-52923646 [Accessed 29/07/2015]

2. Bailey, S.R. et al., (2007) Effect of dietary fructans and dexamethasone administration on the insulin response of ponies predisposed to laminitis. Journal of the American Veterinary Medical Association, 231 (9), pp.1365-1373. http://dx.doi.org/10.2460/javma.231.9.1365

3. Center for Veterinary Medicine Cumulative Adverse Drug Event (ADE) Summaries Report 01/01/198730/04/2013. [U.S. Food and Drug Administration] [online] Available from:

http://www.fda.gov/AnimalVeterinary/SafetyHealth/ProductSafetylnformation/ucm055369.htm [Accessed 29/07/2015]

4. Cohen, N.D. and Carter, G.K. (1992) Steroid hepatopathy in a horse with glucocorticoid-induced hyperadrenocorticism. Journal of the American Veterinary Medical Association, 200 (11), pp. 16821684.

5. Cornelisse, C.J. et al., (2006) Thermographic study of in vivo modulation of vascular responses to phenylephrine and endothelin-1 by dexamethasone in the horse. Equine Veterinary Journal, 38 (2), pp. 119-126. http://dx.doi.org/10.2746/042516406776563251

6. Cripps, P.J. and Eustace, R.A. (1999) Factors involved in the prognosis of equine laminitis in the UK. Equine Veterinary Journal, 31 (5), pp. 433-442.

http://dx.doi.org/10.1111/j.2042-3306.1999.tb03845.x

7. Eyre, P and Elmes, P.J. (1980) Corticosteroid-induced laminitis? Further observations on the isolated, perfused hoof. Veterinary Research Communications, 4 (1), pp. 139-143.

http://dx.doi.org/10.1007/BF02278492

8. Frederick, D.M. and Kehl, M. (2000) Case report: Back from the brink. Equus, 272, pp. 34-41.

9. French, K., Pollitt, C.C. and Pass, M.A. (2000) Pharmacokinetics and metabolic effects of triamcinolone acetonide and their possible relationships to glucocorticoid-induced laminitis in horses. Journal of Veterinary Pharmacology and Therapeutics, 23 (5), pp. 287-292. http://dx.doi.org/10.1111/j.13652885.2000.00288.x

10. Harkins, J.D., Carney, J.M. and Tobin, T. (1993) Clinical use and characteristics of the corticosteroids. Veterinary Clinics of North America: Equine Practice, 9 (3), pp.543-562.

11. Humber, K.A. et al., (1991) Azathioprine for treatment of immune-mediated thrombocytopenia in two horses. Journal of the American Veterinary Medical Association, 199 (5), pp. 591-594.

12. Johnson, P.J. et al., (2002) Glucocorticoids and laminitis in the horse. Veterinary Clinics of North America: Equine Practice, 18 (2), pp. 219-236. http://dx.doi.org/10.1016/s0749-0739(02)00015-9

13. Johnson, P.J. et al., (2004) Endocrinopathic laminitis in the horse. Clinical Techniques in Equine Practice, 3 (1), pp.45-56. http://dx.doi.org/10.1053/j.ctep.2004.07.004

14. Lose, M.P. (1980) Drug-induced laminitis in a colt. Modern Veterinary Practice, 61 (7), pp. 608-610.

15. McCluskey, M.J. and Kavenagh, P.B. (2004) Clinical use of triamcinolone acetonide in the horse (205 cases) and the incidence of glucocorticoid-induced laminitis associated with its use. Equine Veterinary Education, 16 (2), pp. 86-89. http://dx.doi.org/10.1111/j.2042-3292.2004.tb00272.x

16. McGowan, C.M. (2008) The role of insulin in endocrinopathic laminitis. Journal of Equine Veterinary Science, 28 (10), pp. 603-607. http://dx.doi.org/10.1016/j.jevs.2008.08.004

17. Muylle, E. and Oyaert, W. (1973) Lung function tests in obstructive pulmonary disease in horses. Equine Veterinary Journal, 5 (1), pp. 37-44. http://dx.doi.org/10.1111/j.2042-3306.1973.tb03191.x

18. Oxford Levels of Evidence 2 [Oxford Centre for Evidence-Based Medicine - OCEBM Levels of Evidence Working Group] [online] Available from: http://www.cebm.net/index.aspx?o=5653 [Accessed 11/08/2015].

19. Ryu, S. et al., (2004) Glucocorticoid-induced laminitis with hepatopathy in a Thoroughbred filly. Journal of Veterinary Science, 5 (3), pp. 271-274. 
20. Slater, M.R., Hood, D.M. and Carter, G.K. (1995) Descriptive epidemiological study of equine laminitis. Equine Veterinary Journal, 27 (5), pp. 364-367.

http://dx.doi.org/10.1111/j.2042-3306.1995.tb04071.x

21. Tiley, H.A., Geor, R.J. and McCutcheon, L.J. (2007) Effects of dexamethasone on glucose dynamics and insulin sensitivity in healthy horses. American Journal of Veterinary Research, 68 (7), pp.753-759. http://dx.doi.org/10.2460/ajvr.68.7.753

22. Tiley, H.A., Geor, R.J. and McCutcheon, L.J. (2008) Effects of dexamethasone administration on insulin resistance and components of insulin signaling and glucose metabolism in equine skeletal muscle. American Journal of Veterinary Research, 69 (1), pp. 51-58. http://dx.doi.org/10.2460/ajvr.69.1.51

23. Vandenabeele, S.I.J. et al., (2004) Pemphigus foliaceus in the horse: A retrospective study of 20 cases. Veterinary Dermatology, 15 (6), pp. 381-388. http://dx.doi.org/10.1111/j.1365-3164.2004.00423.x

24. Winfield, L.D. et al., (2013) Pemphigus vulgaris in a Welsh pony stallion: Case report and demonstration of antidesmoglein autoantibodies. Veterinary Dermatology, 24 (2) pp. 269-e60 http://dx.doi.org/10.1111/vde.12002 


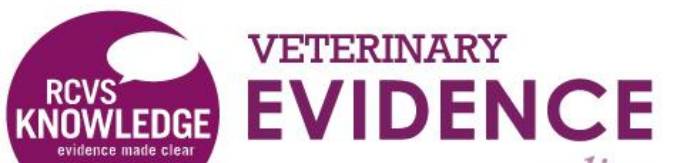 \\ online}

\section{Intellectual Property Rights}

Authors of Knowledge Summaries submitted to RCVS Knowledge for publication will retain copyright in their work, but will be required to grant to RCVS Knowledge an exclusive license of the rights of copyright in the materials including but not limited to the right to publish, re-publish, transmit, sell, distribute and otherwise use the materials in all languages and all media throughout the world, and to license or permit others to do so.

Authors will be required to complete a license for publication form, and will in return retain certain rights as detailed on the form.

Veterinary Evidence and EBVM Network are RCVS Knowledge initiatives. For more information please contact us at editor@veterinaryevidence.org.

RCVS Knowledge is the independent charity associated with the Royal College of Veterinary Surgeons (RCVS). Our ambition is to become a global intermediary for evidence based veterinary knowledge by providing access to information that is of immediate value to practicing veterinary professionals and directly contributes to evidence based clinical decision-making.

\section{www.veterinaryevidence.org}

RCVS Knowledge is a registered Charity No. 230886. Registered as a Company limited by guarantee in England and Wales No. 598443.

Registered Office:

Belgravia House

62-64 Horseferry Road

London SW1P 2AF 